This document was prepared in conjunction with work accomplished under Contract No. DE-AC09-96SR18500 with the U. S. Department of Energy.

\title{
DISCLAIMER
}

This report was prepared as an account of work sponsored by an agency of the United States Government. Neither the United States Government nor any agency thereof, nor any of their employees, nor any of their contractors, subcontractors or their employees, makes any warranty, express or implied, or assumes any legal liability or responsibility for the accuracy, completeness, or any third party's use or the results of such use of any information, apparatus, product, or process disclosed, or represents that its use would not infringe privately owned rights. Reference herein to any specific commercial product, process, or service by trade name, trademark, manufacturer, or otherwise, does not necessarily constitute or imply its endorsement, recommendation, or favoring by the United States Government or any agency thereof or its contractors or subcontractors. The views and opinions of authors expressed herein do not necessarily state or reflect those of the United States Government or any agency thereof. 
WSRC-TR-2004-00424

\section{ESTIMATE OF TRITIUM PERMEATION OUT OF TPBAR WASTE CONTAINER (U)}

Elliot A. Clark

26 August 2004

Westinghouse Savannah River Company Aiken, SC 29808

Prepared for the U.S. Department of Energy under Contract DE-AC09-96SR18500 


\section{DISCLAIMER}

This report was prepared as an account of work sponsored by an agency of the United States Government. Neither the United States Government nor any agency thereof, nor any of their employees, makes any warranty, express or implied, or assumes any legal liability or responsibility for the accuracy, completeness, or usefulness of any information, apparatus, product or process disclosed, or represents that its use would not infringe privately owned rights. Reference herein to any specific commercial product, process or service by trade name, trademark, manufacturer, or otherwise does not necessarily constitute or imply its endorsement, recommendation, or favoring by the United States Government or any agency thereof. The views and opinions of authors expressed herein do not necessarily state or reflect those of the United States Government or any agency thereof. 


\title{
SMTD
}

STRATEGIC MATERIALS TECHNOLOGY DEPARTMENT

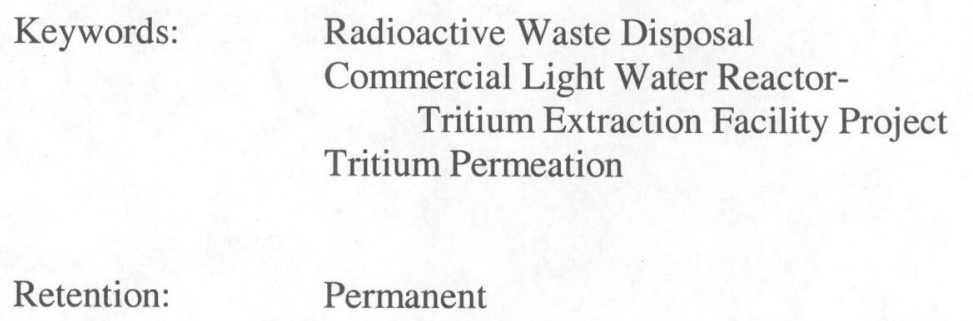

Retention: Permanent

\section{ESTIMATE OF TRITIUM PERMEATION OUT OF TPBAR WASTE CONTAINER (U)}

\author{
Elliot A. Clark \\ Materials Technology Section \\ ISSUED: $\quad 26$ August 2004
}

Unclassified 
SRNL SAVANNAH RIVER NATIONAL LABORATORY, AIKEN, SC 29808

Westinghouse Savannah River Company

Prepared for the U.S. Department of Energy under Contract DE-AC09-96SR18500

Document: $\quad$ WSRC-TR-2004-00424

Title: $\quad$ ESTIMATE OF TRITIUM PERMEATION OUT OF TPBAR WASTE CONTAINER

APPROVALS

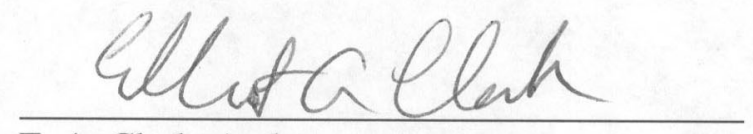

DATE: 19 August 2004

E. A. Clark, Author

MATERIALS COMPATIBILITY AND WELDING TECHNOLOGY GROUP MATERIALS TECHNOLOGY SECTION

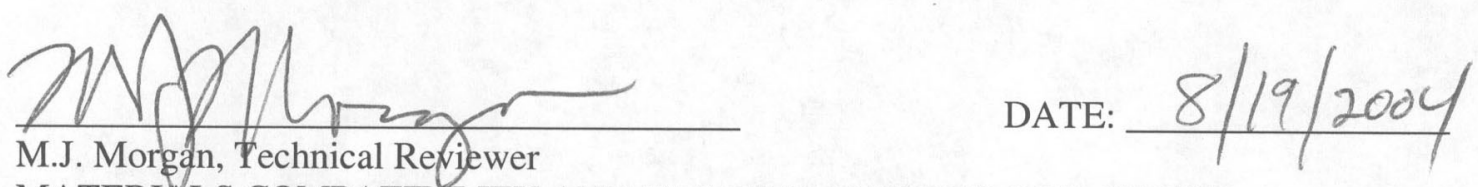

MATERIALS COMPATIBILITY AND WELDING TECHNOLOGY GROUP MATERIALS TECHNOLOGY SECTION

Edctiergesell

R.A. Hiergesel1, Customer
DATE: $8 / 19 / 04$ WASTE PROCESSING TECHNOLOGY SECTION

tart 2. West

DATE: $8 / 24 / 2004$

S. L. West, Manager

MATERIALS COMPATIBILITY AND WELDING TECHNOLOGY GROUP

MATERIALS TECHNOLOGY SECTION

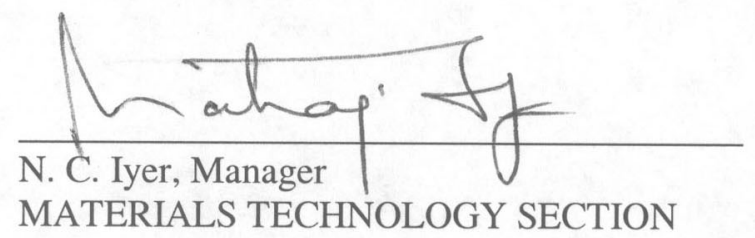

DATE: $8 / 19104$ 


\section{CONTENTS}

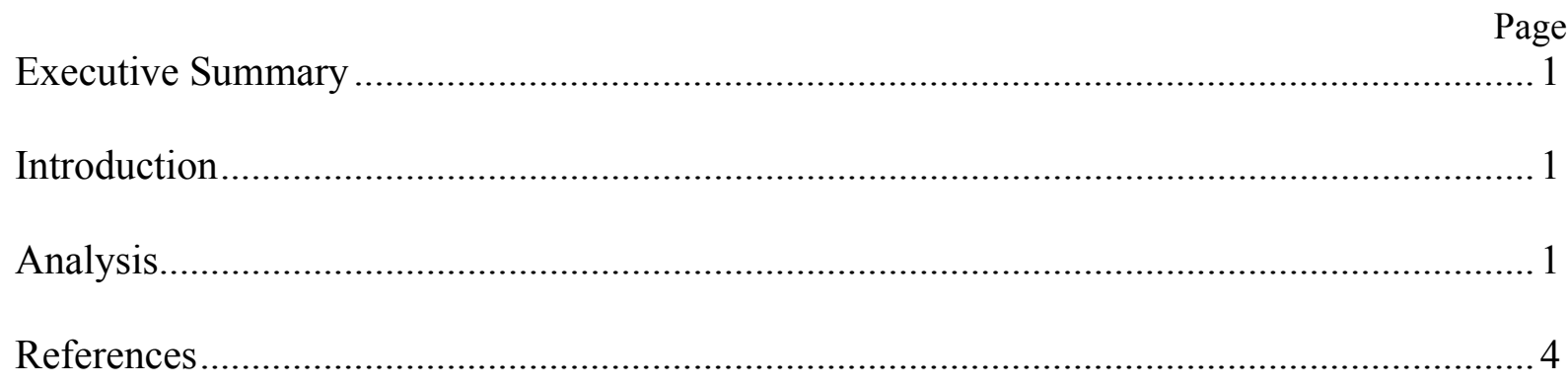

\section{FIGURE}

1. Pictures of top of proposed waste container for CLWR-TEF ...........................................5

\section{TABLES}

I. Calculated yearly tritium permeation through sides, weld, and lid, total permeated each year, remaining tritium each year, and decay corrected remaining tritium each year, $200^{\circ} \mathrm{F}$...... 6

II. Calculated yearly tritium permeation through sides, weld, and lid, total permeated each year, remaining tritium each year, and decay corrected remaining tritium each year, $175^{\circ} \mathrm{F} \ldots . . .7$ 
PAGE INTENTIONALLY BLANK 


\title{
ESTIMATE OF TRITIUM PERMEATION OUT OF TPBAR WASTE CONTAINER
}

\author{
Elliot A. Clark
}

\section{Executive Summary}

The rate of tritium permeating out of a proposed waste container for the Commercial Light Water Reactor- Tritium Extraction Facility is estimated. This estimate conservatively assumes that all of the residual tritium in the already extracted Tritium Producing Burnable Absorber Rods (TPBARs) is available as diatomic gas to permeate the outer container. The permeation rate is calculated for each year after disposal, at two temperatures determined by a separate thermal analysis of this waste form in disposal. All the residual tritium permeates out of the container in 17 years at $200 \mathrm{~F}$ and in 24 years at $175 \mathrm{~F}$. Results of this estimate will be used in a Special Analysis to assess waste disposal options.

\section{Introduction}

The Commercial Light Water Reactor program will produce tritium for Defense Programs using Tritium Producing Burnable Absorber Rods (TPBARs) installed in a light water reactor. Neutron irradiation of the rods in the reactor creates tritium by fission of the isotope lithium- 6 , and the tritium will be trapped in the TPBAR by zirconium and zircaloy getters. Tritium will be thermally extracted from the TPBARs in the new Tritium Extraction Facility at the Savannah River Site, using furnaces designed for this purpose. After extraction, there will be a small amount of residual tritium in the spent TPBARs. The spent TPBARs will be placed inside several containers, and finally will be contained by a carbon steel container designed to shield gamma radiation coming from activated stainless steel cladding of the TPBARs.

In all likelihood the residual tritium in the extracted TPBARs will remain chemically bound as a hydride in the zirconium and zircaloy getters. This analysis evaluates the hypothetical worst-case scenario of all the tritium being immediately released from the getters as tritium gas, and this gaseous tritium permeating the outer waste container. (The interior nested containers of the TPBARs, which include the consolidation container and the furnace extraction basket, are not sealed and so provide no permeation barrier.) The outer container is considered to be the tritium permeation barrier in this analysis. The amount of tritium permeating the outer container each year will be input to a so-called Special Analysis to assess where this waste form can be disposed of.

\section{$\underline{\text { Analysis }}$}

The current design of the outer container is a rectangular box made of SA-516, Grade 70 carbon steel (Fig. 1). Three permeation paths are considered. First, tritium permeates the side walls and bottom of the container. The wall thickness is 13 inches on all sides and the bottom. The internal wall surface that is exposed to the hypothetical tritium gas is a box 36 " by 36 " by 202 ". Second, tritium permeates the outer seal lid. This lid is welded to one end of the container and is 47 " by 47 " by 1" thick (Fig. 1). (No credit is taken for the bolted upper lid, which provides radiation shielding 
for the top, to reduce permeation.) Third, tritium permeates the weld used to attach the outer seal lid. The weld is considered to be $1 / 2$ " deep, $1 / 2$ " wide, and has a length of $4 * 47$ " or 188 ".

The permeability is defined by

$$
\Phi \equiv D \times S
$$

in which $D$ is the diffusivity of tritium in the material $\left(\mathrm{cm}^{2} / \mathrm{s}\right)$ and $S$ is the solubility (here $\mathrm{cc}_{2} @$ $\mathrm{STP} / \mathrm{cc}$ material). The unit of $\Phi$ is $\mathrm{cm}^{2}-\mathrm{cc} \mathrm{H}_{2} @ \mathrm{STP} / \mathrm{s} / \mathrm{cc}$ material. The maximum permeation rate through a material of thickness $\mathrm{L}$ is the so-called steady state flux:

$$
\text { Flux }=\frac{\Phi}{L}
$$

The flux is the amount of tritium $\left(\mathrm{cc} \mathrm{H}_{2} @ \mathrm{STP} / \mathrm{cm}^{2} / \mathrm{s}\right)$ permeating per unit area per unit time. Because of the rapid diffusivity of hydrogen isotopes in this material, the steady state permeation rate is achieved in about one week in 13" thick walls (much faster for the thinner seal lid and weld paths) and so steady state equations describe the permeation occurring over years very accurately.

The diffusivity of hydrogen isotopes in iron is represented by

$$
D=D_{0} * e^{-\frac{Q}{R T}}
$$

where $D_{0}$ is the pre-exponential factor, $\mathrm{Q}$ the activation energy of diffusion, $\mathrm{R}$ is the Gas Constant and $\mathrm{T}$ the absolute temperature. The solubility of hydrogen isotopes in iron is given by Sievert's Law:

$$
S=S_{0} * \sqrt{p} * e^{-\frac{\Delta H}{R T}}
$$

in which $\mathrm{S}_{0}$ is a constant, $\mathrm{p}$ the partial pressure of the solute (in atmospheres), and $\Delta \mathrm{H}$ the heat of solution. Values of the constants $\mathrm{Q}, \mathrm{D}_{0}, \mathrm{~S}_{0}$, and $\Delta \mathrm{H}$ are assumed to be those of protium, ${ }^{1} \mathrm{H}$, for pure iron [1]. The solubility, diffusivity, and permeability of tritium in the material of construction of the container is assumed to be the same as that of pure iron at moderate temperatures (ferrite, or alpha iron). This assumption is reasonably conservative because, in the limited number of systematic studies regarding diffusivity of hydrogen in iron-based alloys, the major alloying elements decrease or have no effect on hydrogen diffusivity [2].

Thermal calculations indicate that the maximum temperature in the interior of the container (within the spent rods) is $200^{\circ} \mathrm{F}$, and the maximum temperature at the interior surface of the carbon steel permeation boundary is $175^{\circ} \mathrm{F}$ [3]. Results of permeation rates out of the container will be given for these two temperatures. Information from the project gives the residual tritium in each rod as $133 \mathrm{Ci}$. Each furnace basket is assumed to contain 300 rods, and for the first container disposed, three of the normal extracted baskets will be disposed of. (The fourth position in the container will be occupied by the container containing the unused Lead Test Assembly test TPBARs. Tritium 
permeation will be calculated for this container separately and is not considered in this analysis.) Thus, the total tritium content of the container that can permeate the carbon steel is $133 \mathrm{Ci} / \mathrm{rod}$ * 300 rods $* 3$ extraction baskets $=119,700 \mathrm{Ci}$. The unoccupied fraction of the total container volume inside the carbon steel wall is assumed to be $20 \%$. The free volume $v^{\text {free }}$ is the container volume inside the permeation boundary multiplied by the free volume fraction- the free volume is the volume the hypothetical tritium gas occupies. The amount of tritium in cc at Standard Temperature and Pressure (STP) $v^{\text {stdcc }}$ is the amount of tritium in Ci divided by 2.589 [4]. The hypothetical tritium partial pressure in the free volume $p$ of the container is found by:

$$
p=\frac{v^{\text {stdcc }} \cdot T}{v^{\text {free }} \cdot 273}
$$

in which $\mathrm{T}$ is the absolute temperature (Kelvin). Note the partial pressure depends on the assumed temperature in Eq. 5.

The diffusivity (Eq. 3) and solubility (Eq. 4) are calculated using the assumed temperatures and partial pressures (Eq. 5). The permeability (Eq. 1) and the flux (Eq. 2) are then calculated for each permeation path (note the different paths have different thicknesses, Eq. 2). Finally, the total amount of tritium permeating each path is found by multiplying the surface area of the path by its flux. This calculation has been implemented as a spreadsheet that results in the calculation of the steady state permeation rate, expressed in $\mathrm{Ci} / \mathrm{year}$, for each of the three permeation paths.

The rapid permeation of tritium in this hypothetical scenario results in a declining tritium partial pressure inside the container. This occurs because permeation reduces the amount of tritium in the container, $v^{\text {stdcc }}$, and so the partial pressure is reduced, Eq. 5, thus reducing the solubility at the internal surface, Eq. 4. To account for this, a separate spreadsheet calculates the declining permeation rate for each permeation path for each year sequentially. A constant permeation rate is used during each year, and the rate is adjusted for the next year based on the reduction of tritium in the container each year. In addition, radioactive decay of tritium inside the container further reduces the tritium partial pressure. This decay is also applied in the spreadsheet, using the tritium half life 12.3 years [4].

Table I displays the yearly tritium permeation through each path, the total permeated each year, as well as the amount remaining before and after calculating the reduction from radioactive decay, assuming $200^{\circ} \mathrm{F}$. Table II displays the same results for $175^{\circ} \mathrm{F}$. All the residual tritium permeates out of the container in 17 years at $200 \mathrm{~F}$ and in 24 years at $175 \mathrm{~F}$. 


\section{References}

1. N.R. Quick and H.H. Johnson. "Hydrogen and Deuterium in Iron, 49-506 ${ }^{\circ}$ ". Acta Metallurgica, Vol. 26 pp 903-907 (1978).

2. P. Kedzierzawski, "Diffusivity of Hydrogen and Its Isotopes in Iron Alloys", Chapter 12 in Hydrogen Decradation of Ferrous Alloys, ed. R.A. Oriani, J.P. Hirth, and M. Smialowski, Noyes Publications, Park Ridge, New Jersey USA (1985), p. 267.

3. D.W. Vinson, K.H. Subramanian, and E.A. Clark. "Containment Materials Performance for TPBAR Disposal”, Report WSRC-TR-2004-00374, Westinghouse Savannah River Company, Aiken, SC 29808, July 2004.

4. DOE Handbook: Primer on Tritium Safe Handling Practices. US Department of Energy Report DOE-HDBK-1079-94 (December 1994). 


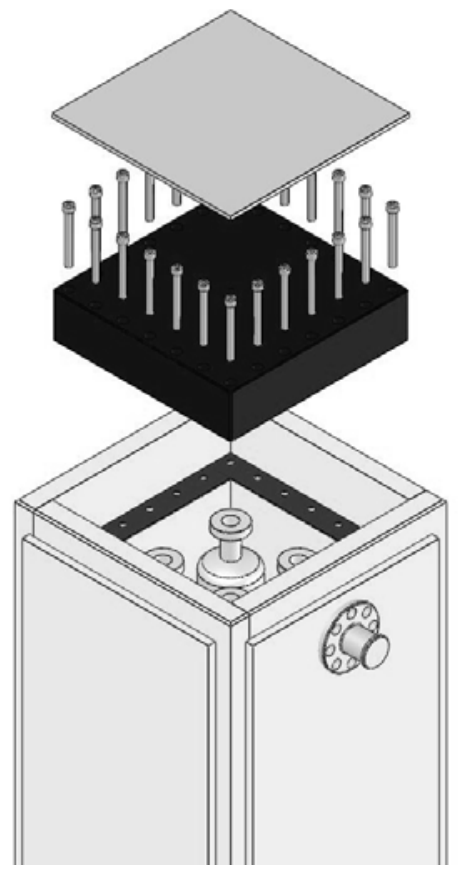

a.

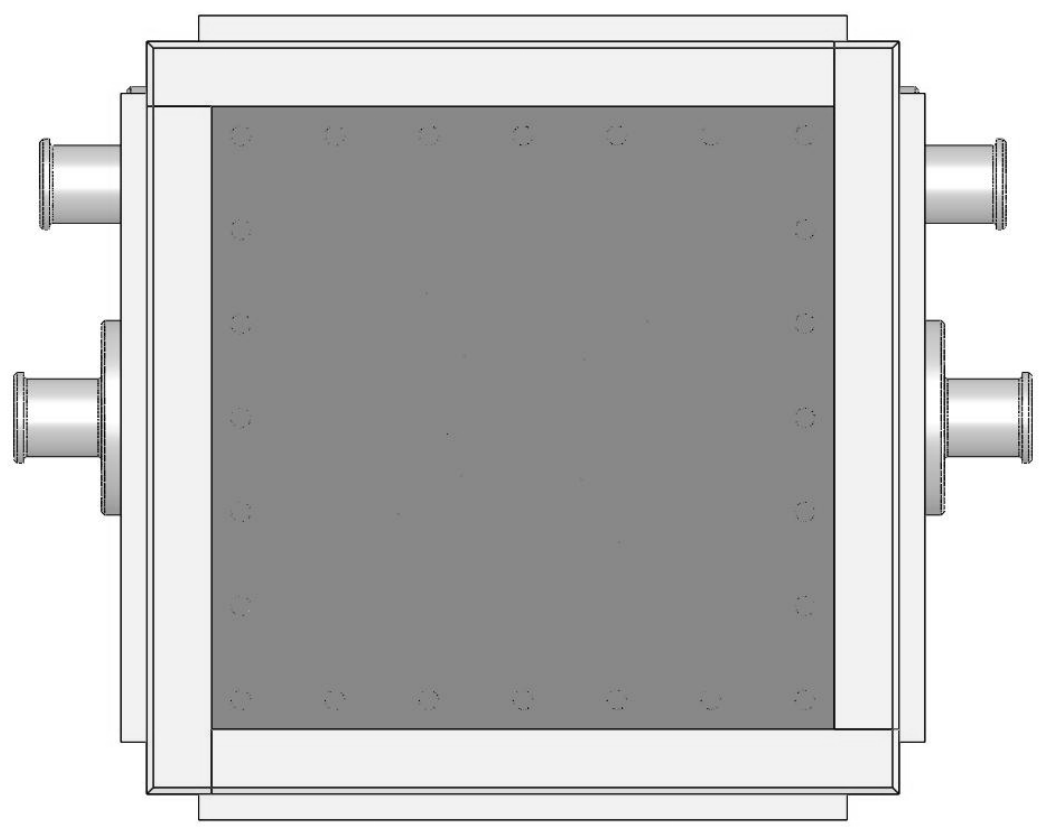

b.

Figure 1. Pictures of top of proposed waste container for CLWR-TEF: a. exploded view of upper radiation shield and outer seal lid; b. Top after welding outer seal lid. 


\begin{tabular}{|c|c|c|c|c|c|c|}
\hline Year & $\begin{array}{l}\text { deg. F } \\
\frac{\text { Sides \& }}{\text { Bottom }}\end{array}$ & Weld & Lid & $\frac{\text { Ci Permeated }}{\text { Each Year }}$ & 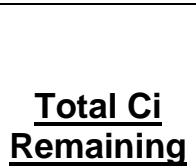 & $\frac{\frac{\text { Total Ci }}{\text { Decay }}}{\text { Correct }}$ \\
\hline 0 & & & & & & 119700 \\
\hline 1 & 5273 & 407 & 4780 & 10459 & 109241 & 103255 \\
\hline 2 & 4897 & 378 & 4439 & 9714 & 93540 & 88415 \\
\hline 3 & 4532 & 350 & 4108 & 8989 & 79426 & 75073 \\
\hline 4 & 4176 & 322 & 3785 & 8283 & 66790 & 63130 \\
\hline 5 & 3829 & 295 & 3471 & 7596 & 55535 & 52492 \\
\hline 6 & 3492 & 269 & 3165 & 6926 & 45565 & 43068 \\
\hline 7 & 3163 & 244 & 2867 & 6274 & 36795 & 34778 \\
\hline 8 & 2842 & 219 & 2576 & 5638 & 29140 & 27544 \\
\hline 9 & 2529 & 195 & 2293 & 5017 & 22526 & 21292 \\
\hline 10 & 2224 & 172 & 2016 & 4411 & 16881 & 15956 \\
\hline 11 & 1925 & 149 & 1745 & 3819 & 12137 & 11472 \\
\hline 12 & 1632 & 126 & 1480 & 3238 & 8234 & 7783 \\
\hline 13 & 1345 & 104 & 1219 & 2667 & 5116 & 4835 \\
\hline 14 & 1060 & 82 & 961 & 2102 & 2733 & 2583 \\
\hline 15 & 775 & 60 & 702 & 1537 & 1047 & 990 \\
\hline 16 & 479 & 37 & 435 & 951 & 39 & 36 \\
\hline 17 & 92 & 7 & 83 & 182 & 0 & 0 \\
\hline 18 & 0 & 0 & 0 & 0 & 0 & 0 \\
\hline 19 & 0 & 0 & 0 & 0 & 0 & 0 \\
\hline 20 & 0 & 0 & 0 & 0 & 0 & 0 \\
\hline 21 & 0 & 0 & 0 & 0 & 0 & 0 \\
\hline 22 & 0 & 0 & 0 & 0 & 0 & 0 \\
\hline 23 & 0 & 0 & 0 & 0 & 0 & 0 \\
\hline 24 & 0 & 0 & 0 & 0 & 0 & 0 \\
\hline 25 & 0 & 0 & 0 & 0 & 0 & 0 \\
\hline
\end{tabular}

Table I. Calculated yearly tritium permeation through sides, weld, and lid, total permeated each year, remaining tritium each year, and decay corrected remaining tritium each year. Temperature is $200^{\circ} \mathrm{F}$. All tritium amounts in $\mathrm{Ci}$ (curies). 


\begin{tabular}{|c|c|c|c|c|c|c|}
\hline Year & $\begin{array}{l}\text { deg. F } \\
\text { Sides \& } \\
\text { Bottom }\end{array}$ & Weld & Lid & $\frac{\text { Ci Permeated }}{\text { Each Year }}$ & $\begin{array}{c}\text { Total Ci } \\
\text { Remaining }\end{array}$ & $\frac{\text { Total Ci }}{\text { Decay }}$ \\
\hline 0 & & & & & & 119700 \\
\hline 1 & 3259 & 251 & 2954 & 6465 & 113235 & 107030 \\
\hline 2 & 3082 & 238 & 2794 & 6113 & 100917 & 95388 \\
\hline 3 & 2909 & 224 & 2637 & 5771 & 89616 & 84706 \\
\hline 4 & 2742 & 212 & 2485 & 5438 & 79268 & 74924 \\
\hline 5 & 2578 & 199 & 2337 & 5115 & 69809 & 65984 \\
\hline 6 & 2420 & 187 & 2193 & 4800 & 61184 & 57832 \\
\hline 7 & 2265 & 175 & 2053 & 4494 & 53338 & 50415 \\
\hline 8 & 2115 & 163 & 1917 & 4196 & 46220 & 43687 \\
\hline 9 & 1969 & 152 & 1785 & 3906 & 39782 & 37602 \\
\hline 10 & 1827 & 141 & 1656 & 3623 & 33978 & 32117 \\
\hline 11 & 1688 & 130 & 1530 & 3349 & 28768 & 27192 \\
\hline 12 & 1553 & 120 & 1408 & 3081 & 24110 & 22789 \\
\hline 13 & 1422 & 110 & 1289 & 2821 & 19968 & 18874 \\
\hline 14 & 1294 & 100 & 1173 & 2567 & 16307 & 15414 \\
\hline 15 & 1170 & 90 & 1060 & 2320 & 13094 & 12376 \\
\hline 16 & 1048 & 81 & 950 & 2079 & 10297 & 9733 \\
\hline 17 & 929 & 72 & 842 & 1843 & 7890 & 7457 \\
\hline 18 & 813 & 63 & 737 & 1614 & 5844 & 5524 \\
\hline 19 & 700 & 54 & 635 & 1389 & 4135 & 3908 \\
\hline 20 & 589 & 45 & 534 & 1168 & 2740 & 2590 \\
\hline 21 & 479 & 37 & 435 & 951 & 1639 & 1549 \\
\hline 22 & 371 & 29 & 336 & 735 & 814 & 769 \\
\hline 23 & 261 & 20 & 237 & 518 & 251 & 237 \\
\hline 24 & 145 & 11 & 132 & 288 & 0 & 0 \\
\hline 25 & 0 & 0 & 0 & 0 & 0 & 0 \\
\hline
\end{tabular}

Table II. Calculated yearly tritium permeation through sides, weld, and lid, total permeated each year, remaining tritium each year, and decay corrected remaining tritium each year. Temperature is $175^{\circ} \mathrm{F}$. All tritium amounts in $\mathrm{Ci}$ (curies). 
Distribution:

\begin{tabular}{|l|l|}
\hline R.A. Hiergesell & $773-42 \mathrm{~A}$ \\
\hline E.L. Wilhite & $773-43 \mathrm{~A}$ \\
\hline J.R. Cook & $773-43 \mathrm{~A}$ \\
\hline B.T. Butcher & $773-43 \mathrm{~A}$ \\
\hline W.E. Stevens & $773-\mathrm{A}$ \\
\hline K.L. Tempel & $724-5 \mathrm{E}$ \\
\hline W.F. Brizes & $233-34 \mathrm{H}$ \\
\hline B.C. Patel & $742-14 \mathrm{G}$ \\
\hline C.A. Flavin & $233-34 \mathrm{H}$ \\
\hline W.T. Goldston & $705-3 \mathrm{C}$ \\
\hline S.L. West & $773-\mathrm{A}$ \\
\hline N.C. Iyer & $773-41 \mathrm{~A}$ \\
\hline M.J. Morgan & $773-\mathrm{A}$ \\
\hline Scientific and Technical Information (3 copies) & $703-43 \mathrm{~A}$ \\
\hline MTS Files & $773-41 \mathrm{~A}$ \\
\hline
\end{tabular}

